\title{
Effects of ad libitum or restricted access to total mixed ration with supplemental long hay on production, intake, and rumination
}

\author{
D. Cavallini, ${ }^{*}$ L. M. E. Mammi, ${ }^{*}$ M. Fustini, ${ }^{*}$ A. Palmonari, ${ }^{*}$ A. J. Heinrichs,,${ }^{1}$ and A. Formigoni ${ }^{*}$ \\ *Department of Veterinary Medicine, Università di Bologna, 40064, Bologna, Italy \\ †Department of Animal Science, Pennsylvania State University, University Park 16802
}

\section{ABSTRACT}

Limiting feeding time has been a concept used in growing and nonlactating ruminant animals with good success, especially in improving feed efficiency while maintaining normal rumen function and fiber digestibility. This study evaluated the physiological and productive responses of cows fed a total mixed ration (TMR) available for 24 or $19 \mathrm{~h} / \mathrm{d}$ with or without access to additional long hay. Eight multiparous Holstein cows were used in a replicated $4 \times 4$ Latin square design with 21-d periods. Rations were formulated to mimic a TMR used in the Parmigiano Reggiano cheese production area of Italy, consisting of all dry and nonfermented components. Intakes were reduced by $2.49 \mathrm{~kg} / \mathrm{d}$ in cows with restricted TMR access and $1.16 \mathrm{~kg} / \mathrm{d}$ without supplemental hay. Rumen characteristics were similar for all groups with improvements in energy-corrected milk. The results show that once cows adapted to diet changes, few differences were observed when offering TMR continuously or with limited access. Energy-corrected milk feed efficiency was improved in cows having access to feed 19 versus $24 \mathrm{~h} / \mathrm{d}$. In addition, the presence of long hay during the TMR restriction offered the optimal conditions for ruminal function and $\mathrm{pH}$ stability, yet no effects were observed on body weight change. A Latin square with 21-d periods could have a carry-over effect on energy storage, and mobilization of fat reserves might be able to mask negative energy balance during restriction. Restricted feeding could be used as a strategy to manage feed availability according to cow production and metabolic condition, to maximize the use of nutrient resources, reducing the cost of milk production and improving the cows' welfare and health.

Key words: limit feeding, lactating dairy cow, rumination

Received March 19, 2018.

Accepted August 11, 2018.

${ }^{1}$ Corresponding author: ajh@psu.edu

\section{INTRODUCTION}

Total mixed rations with dry hay as the only forage source are widely used in the Parmigiano Reggiano production area of Italy. Typically, little to no water is added to the TMR to avoid the risk of fermentation in the manger. In this situation, particle size of the feed must be reduced to prevent feed sorting, and therefore physically effective NDF (peNDF) is generally below what is commonly considered acceptable (Fustini et al., 2016). This may lead to a reduction of rumination time and saliva secretion thereby leading to SARA (Khafipour et al., 2009). Italian hays are often of low quality and reduced nutrient value due to the climatic conditions (Palmonari et al., 2016), which often necessitates an increased amount of concentrate in the diet to satisfy the energy requirements of lactating cows. Adequate forage particle size in the ration is therefore critical to maintain rumen function and milk components. Furthermore, peNDF promotes chewing and salivary secretion, and maintaining rumen conditions for VFA absorption, which improves $\mathrm{pH}$ stability in the rumen (Mertens, 1977, 1997). In a recent study, Kmicikewycz and Heinrichs (2014) concluded that supplementing rations with long hay favored the recovery of animals with SARA in early and mid lactation. Moreover, inclusion of long hay in low proportions, particularly in diets based on finely chopped silages, has been shown to improve rumination time (Beauchemin et al., 1994).

Dairy cows may also be able to select in favor of longer particles if rumen $\mathrm{pH}$ and rumination levels are low. Maulfair et al. (2013) saw that during SARA cows were able to change their eating preferences in favor of diets with more long forage and lower contents of fermentable starch. Keunen et al. (2002) also showed that lactating cows with induced SARA increased their preference for long alfalfa hay compared with alfalfa pellets. It has been suggested that under conditions of reduced ruminal $\mathrm{pH}$, if given an option, cows will choose feeds with more buffering capacity (DeVries et al., 2008).

Limit feeding has been used in ruminant animals with good success, especially in improving feed effi- 
ciency while maintaining normal rumen function and digestibility (Owens et al., 1995). Limit feeding often improves digestibility (Zanton and Heinrichs, 2008), primarily through reducing the rate of passage of material from the reticulo-rumen of animals that are fed less (Bhatti et al., 2008). However, few trials based on this concept have been conducted with cows in mid lactation.

The purpose of this experiment was to evaluate the physiological and productive response in cows fed a dry, finely chopped TMR administered for a 24 or $19 \mathrm{~h} / \mathrm{d}$, with or without additional free choice long hay. The hypothesis was that cows having limited access to TMR would result in faster eating rates and lead to changes in rumen $\mathrm{pH}$ and that offering long hay in addition would stabilize rumen $\mathrm{pH}$ and production.

\section{MATERIALS AND METHODS}

This study was conducted at the University of Bologna (Italy), and all experimental procedures involving animals were approved by the University of Bologna Animal Care and Use Committee.

\section{Experimental Design and Data Collection}

Eight multiparous Holstein cows (average BW \pm SD: $629 \pm 49 \mathrm{~kg})$ were blocked by parity $(2.25 \pm 0.46)$, milk production $(44.9 \pm 2.5 \mathrm{~kg} / \mathrm{d})$, and DIM $(99 \pm$ $49)$ and used in a replicated $4 \times 4$ Latin square design study with 21 -d periods (14 d adaptation and $7 \mathrm{~d}$ collection). Rations were formulated using DinaMilk5 (Fabermatica, Ostiano, Italy) to mimic TMR used in the Parmigiano Reggiano cheese production area of Italy and consisted of all dry and nonfermented components. The basal diet was the same for all 4 treatments with or without access to additional long grass hay, which was the same source of hay used in the TMR (Table 1). Diets were offered in individual feed mangers divided in 2 equal parts, one for the TMR and the other for the long grass hay. Cows were offered ad libitum intake of TMR for 24 or $19 \mathrm{~h} / \mathrm{d}$; TMR (approximately $1.10 \times$ expected intake) both were fed once a day at $2000 \mathrm{~h}$ (Zago Mixer, Padova, IT). The study was conducted during the months of September through December, and feeding was done at a time to encourage intake in the evening hours. Animals were housed in a naturally ventilated tiestall barn and milked twice a day $(0800$ and $1930 \mathrm{~h}$ ) in a double-5 herringbone milking parlor. Treatments were identified by the length of TMR access as 24 or $19 \mathrm{~h}$, with $(\mathbf{F}+)$ or without $(\mathbf{F}-)$ ad libitum long grass hay.

From d 15 to 21 of each period, we collected data and took samples. Body weight was measured daily
(Afiweight scale, Afikim, Israel), and DMI was determined by recording feed offered and refused for each cow. Samples of diets and orts were collected daily and a portion of each sample was dried in a forced-air oven at $105^{\circ} \mathrm{C}$ for $24 \mathrm{~h}$ for $\mathrm{DM}$ determination. Milk yield was recorded daily (Afimilk Information Management System, Afikim, Israel) during d 15 to 21 of each period. Milk samples from 2 consecutive milkings for each cow were collected on d 17 and 18 of each period, preserved (Bronolab-W II Liquid Preservative; D \& F Control Systems Inc., Dublin, CA), and analyzed for fat, true protein, and lactose by infrared spectroscopy

Table 1. Composition of the TMR diet and the hay (mean \pm SD)

\begin{tabular}{lrr}
\hline Item & \multicolumn{1}{c}{ TMR $^{1}$} & \multicolumn{1}{c}{ Hay } \\
\hline DM, \% & $87.66 \pm 0.72$ & $88.54 \pm 2.93$ \\
Ether extract, \% of DM & $2.53 \pm 0.38$ & $1.64 \pm 0.20$ \\
Ash, \% of DM & $9.76 \pm 0.37$ & $8.93 \pm 0.63$ \\
aNDFom, \% of DM & $31.44 \pm 5.45$ & $58.46 \pm 3.45$ \\
ADF, \% of DM & $20.77 \pm 4.18$ & $42.61 \pm 1.62$ \\
ADL, \% of DM & $2.94 \pm 0.64$ & $6.62 \pm 0.80$ \\
IVNDFD ${ }^{3}$ 24 h, \% of aNDFom & $77.33 \pm 6.95$ & $67.02 \pm 3.21$ \\
d-NDF 24 h, $\%$ of aNDFom & $45.51 \pm 3.44$ & $44.74 \pm 5.27$ \\
uNDF $240, \%$ of DM & $6.40 \pm 1.98$ & $17.82 \pm 5.40$ \\
Starch, \% of DM & $23.55 \pm 4.78$ & $1.98 \pm 2.12$ \\
Sugar, \% of DM & $6.96 \pm 0.56$ & $4.79 \pm 0.66$ \\
CP, \% of DM & $14.28 \pm 0.90$ & $8.76 \pm 1.10$ \\
Soluble protein, \% of DM & $3.91 \pm 0.44$ & $3.55 \pm 0.37$ \\
NDIP $\%$ of DM & $3.00 \pm 0.28$ & $4.92 \pm 0.65$ \\
ADIP, \% of DM & $1.01 \pm 0.07$ & $1.55 \pm 0.15$ \\
PSPS & & \\
19 mm, \% & & \\
8 mm, \% & $0.39 \pm 0.79$ & \\
4 mm, \% & $15.18 \pm 5.10$ & \\
Bottom, \% & $18.73 \pm 1.92$ & \\
Ro-Tap, \% >1.18 mm & $65.69 \pm 5.60$ & \\
peNDF, \% of DM & $46.24 \pm 3.90$ & \\
\hline
\end{tabular}

${ }^{1}$ TMR ingredients: $34.5 \%$ grass hay, $19.2 \%$ steam flaked corn, $3.9 \%$ cane-beet molasses blend, and $42.4 \%$ grain mix $\{29.6 \%$ wheat bran, $29.4 \%$ sorghum grain, $21.6 \%$ soybean meal, $14.7 \%$ flaked soybean, $2.2 \%$ calcium carbonate, $1 \%$ sodium chloride, $0.4 \%$ magnesium oxide, $0.9 \%$ sodium bentonite, and $0.3 \%$ vitamin and mineral premix [provided 40,000 IU of vitamin $\mathrm{A}, 4,000 \mathrm{IU}$ of vitamin $\mathrm{D}_{3}, 30 \mathrm{mg}$ of vitamin $\mathrm{E} 92 \%$-tocopherol, $5 \mathrm{mg}$ of vitamin $\mathrm{B}_{1}, 3 \mathrm{mg}$ of vitamin $\mathrm{B}_{2}, 1.5$ $\mathrm{mg}$ of vitamin $\mathrm{B}_{6}, 0.06 \mathrm{mg}$ of vitamin $\mathrm{B}_{12}, 5 \mathrm{mg}$ of vitamin $\mathrm{K}, 5 \mathrm{mg}$ of vitamin $\mathrm{H}_{1}$ (para-aminobenzoic acid), $150 \mathrm{mg}$ of vitamin $\mathrm{PP}$ (niacin), $50 \mathrm{mg}$ of choline chloride, $100 \mathrm{mg}$ of Fe, $1 \mathrm{mg}$ of Co, $5 \mathrm{mg}$ of I, $120 \mathrm{mg}$ of $\mathrm{Mn}, 10 \mathrm{mg}$ of $\mathrm{Cu}$, and $130 \mathrm{mg}$ of $\mathrm{Zn}]$ \}.

${ }^{2}$ Amylase- and sodium sulfite-treated NDF with ash correction.

${ }^{3}$ In vitro NDF digestibility, in \% aNDFom.

${ }^{4}$ Digestible NDF at $24 \mathrm{~h}$.

${ }^{5}$ Unavailable NDF estimated via $240-\mathrm{h}$ in vitro fermentation.

${ }^{6}$ Neutral detergent insoluble protein (neutral detergent insoluble nitrogen $\times 6.25$ ).

${ }^{7}$ Acid detergent insoluble protein (acid detergent insoluble nitrogen $\times 6.25)$.

${ }^{8}$ Penn State Particle Separator, \% sample retained on each sieve (Lammers et al., 1996).

${ }^{9}$ Physically effective NDF (aNDFom $\times$ physical effectiveness factor), calculated using the Ro-Tap (W.S. Tyler, Mentor, OH) system (Mertens, 1997). 
procedures (Associazione Provinciale Allevatori Bologna, Foss 4000, Foss Technology). Feed efficiency (kg/ $\mathrm{kg}$ ) was calculated as milk/DMI, 3.5\% FCM/DMI, and solids-corrected milk/DMI during the experimental week.

\section{Rumen Characteristics}

Cows were monitored for rumination activity from d 15 to 20 of each period using the Hi-Tag rumination monitoring system (SCR Engineers Ltd., Netanya, Israel). Data Flow software analyzed rumination time with a resolution of $2 \mathrm{~h}$ (Schirmann et al., 2009) and calculated the rumination time during the last $24 \mathrm{~h}$. To continuously monitor rumen $\mathrm{pH}$, all cows received an indwelling wireless pH-transmitting unit (SmaXtec Animal Care Sales GmbH, Graz, Austria), which has been validated with rumen-cannulated dairy cows (Klevenhusen et al., 2014). These units $(3.5 \mathrm{~cm}$ i.d., $12 \mathrm{~cm}$ long, and weighing $210 \mathrm{~g}$ ) were manually inserted into the reticulorumen via the esophagus on d 14 of the first period. Prior to this, the units were calibrated following the company's instruction protocol (www.smaxtec .com). The units measured $\mathrm{pH}$ and temperature every $10 \mathrm{~min}$ and transmitted the data in real time to a base station using the ISM band (433 MHz). Both data of $\mathrm{pH}$ and temperature were collected using an analogto-digital converter and stored in an external memory chip. Data of $\mathrm{pH}$ from d 15 to 21of each period were analyzed as daily mean $\mathrm{pH}$ and time $(\mathrm{min} / \mathrm{d})$ below specific cut-off points (5.5 and 5.8). Wireless sensors were located in the ventral reticulorumen (Gasteiner et al., 2009), and few differences were observed between $\mathrm{pH}$ measured by wireless units in the rumen and in the ventral rumen sac (Klevenhusen et al., 2014), the term "reticuloruminal $\mathrm{pH}$ " will be used.

On d 5 and 6 of experimental week, rumen fluid was collected via esophageal probe at $12 \mathrm{~h}(0800 \mathrm{~h})$ and $24 \mathrm{~h}(2000 \mathrm{~h})$ after feeding The first $500 \mathrm{~mL}$ of rumen fluid collected was discarded before taking samples. Volatile fatty acid concentrations were determined by GC (Goetsch and Galyean, 1983), whereas ammonia was evaluated via commercial kit (urea/BUN - color, BioSystems S.A. Barcelona, Spain) according to the producer procedure.

\section{Chemical Analysis}

Individual feed ingredients were collected weekly and dried in a forced-air oven at $55^{\circ} \mathrm{C}$ for $48 \mathrm{~h}$ for DM. During the experimental week of each period, diets were sampled daily and analyzed for chemical composition according the following methods: CP; amylase-treated, ash-corrected NDF (aNDFom); and ADF according to
Mertens et al. (2002) and AOAC method 973.18 (AOAC International, 2016). Starch was determined according to AOAC method 996.11 and ether extract according to AOAC method 920.390020 (AOAC International, 2016). Forage and diet composite samples were used to determine particle size distribution on an as-fed basis using the Penn State Particle Separator (Lammers et al., 1996), physical effectiveness factor using a RoTap Separator (W.S. Tyler, Mentor, OH). Diet peNDF was calculated as the product of the total diet NDF content and its physical effectiveness factor (Mertens, 1997). In vitro digestibility $(24,48$, and $240 \mathrm{~h}$ ) of aNDFom of forage composite and diet composite samples (1-mm grind; Wiley mill; Arthur H. Thomas, Philadelphia, PA) were determined using an in vitro fermentation (Tilley and Terry, 1963) in buffered medium containing ruminal fluid (Goering and Van Soest, 1970). Ingredients and diets were also analyzed for in vitro aNDFom digestibility at 24 and $240 \mathrm{~h}$ according to the procedure described by Palmonari et al. (2017). Briefly, in vitro aNDFom digestibility at 24 and $240 \mathrm{~h}$ was performed using the Tilley and Terry modified technique (Tilley and Terry, 1963; Van Soest et al., 1991).

\section{Statistical Analysis}

Data for DMI, milk yield and composition, feed efficiency, microbial protein supply, and BW, and were analyzed as a replicated Latin square design with model effects for diet, period, and replicate using the MIXED procedure of SAS (version 9.1, SAS Institute Inc., Cary, NC) using cow within replicate as a random effect. Repeated measurements on performance data (i.e., DMI, milk yield, and so on) were reduced to period means for each cow before statistical analysis. Data for ruminal $\mathrm{pH}, \mathrm{NH}_{3} \mathrm{~N}$, and VFA were analyzed with repeated measures using the MIXED procedure of SAS. The model included effects of diet, period, time, and the interaction of diet and time, with cow as a random effect. Interaction terms were tested and found nonsignificant and therefore were not included in the final models except for rumination time, which is noted in the table. Least squares means were separated using PDIFF option with Tukey's adjusted $P$-values when a significant $F$-test $(P \leq 0.05)$ was detected.

\section{RESULTS AND DISCUSSION}

The TMR fed was adequate in terms of nutrient composition (NRC, 2001) but smaller in particle size (peNDF $=14.14 \pm 1.30 \%)$ than what is often recommended (peNDF of 21: Heinrichs, 2013; Kmicikewycz et al., 2015; Table 1). This level of dietary particle size minimized the risk of cows sorting (Maulfair et al., 2011; 
Table 2. Effect of feed restriction and supplemental hay ${ }^{1}$ on DMI and fiber fraction intake

\begin{tabular}{|c|c|c|c|c|c|c|c|}
\hline \multirow[b]{3}{*}{ Item } & \multicolumn{4}{|c|}{ Feed availability } & \multirow[b]{3}{*}{ SEM } & \multirow{2}{*}{\multicolumn{2}{|c|}{$P$-value }} \\
\hline & \multicolumn{2}{|c|}{$24 \mathrm{~h}$} & \multicolumn{2}{|c|}{$19 \mathrm{~h}$} & & & \\
\hline & $\mathrm{F}+$ & $\mathrm{F}-$ & $\mathrm{F}+$ & $\mathrm{F}-$ & & 24 vs. $19 \mathrm{~h}$ & $\mathrm{~F}+$ vs. $\mathrm{F}-$ \\
\hline TMR DMI, kg & 27.36 & 24.60 & 23.27 & 23.71 & 1.66 & 0.04 & 0.31 \\
\hline Hay DMI, $\mathrm{kg}$ & 0.55 & - & 0.70 & - & 0.09 & 0.09 & - \\
\hline DMI, $\mathrm{kg}$ & 27.85 & 24.56 & 24.05 & 23.65 & 1.70 & 0.06 & 0.13 \\
\hline aNDFom, $\%$ of BW & 9.39 & 9.48 & 9.31 & 9.51 & 0.34 & 0.83 & 0.24 \\
\hline $\mathrm{uNDF},{ }^{3} \mathrm{~kg} / \mathrm{d}$ & 1.89 & 1.60 & 1.70 & 1.57 & 0.12 & 0.17 & 0.02 \\
\hline uNDF, $\%$ of BW & 0.30 & 0.26 & 0.26 & 0.25 & 0.02 & 0.25 & 0.19 \\
\hline
\end{tabular}

${ }^{1} \mathrm{~F}+=$ supplemental hay; $\mathrm{F}-=$ no supplemental hay.

${ }^{2}$ Amylase- and sodium sulfite-treated NDF with ash correction.

${ }^{3}$ Unavailable NDF estimated via 240 -h in vitro fermentation.

Fustini et al., 2016). When cows were offered TMR 24 vs. $19 \mathrm{~h} / \mathrm{d}$, TMR DMI increased (25.98 vs. $23.49 \mathrm{~kg}$, $\mathrm{SEM}=1.66, P=0.04$, Table 2). Supplemental hay intake was similar between diets. Consequently, total DMI tended to be greater for cows with 24-h TMR access $(26.21$ vs. $23.85 \mathrm{~kg}, \mathrm{SEM}=1.70, P=0.06$, Table 2) compared with cows offered TMR $19 \mathrm{~h} / \mathrm{d}$. Diets including hay tended to increase total NDF intake $(8.26$ vs. $7.55 \mathrm{~kg} / \mathrm{d}, \mathrm{SEM}=0.54, P=0.07$, Table 2$)$. When hay was offered in addition to TMR, cows consumed relatively little hay $(<1 \mathrm{~kg} / \mathrm{d})$ and tended to consume more hay when TMR was offered for 19 versus $24 \mathrm{~h} / \mathrm{d}$. However, this hay intake was not equal to the reduction in TMR intake, likely due to feed palatability or preference for the TMR over the hay alone. A change in eating behavior may have occurred and may fall into the category of slug feeding once cows had adapted to this feeding (19 vs. $24 \mathrm{~h}$ ) change (Fustini et al., 2016). According to other authors (Albright, 1993; Maulfair et al., 2013), animals modified their eating behavior after adaptation to a different feeding regimen. It was thought that when dairy cows had a limited amount of TMR, it would result in faster eating rates, which could lead to substantial diurnal changes in VFA production and increase the risk of SARA (Van Soest, 1994). Previous work (Kmicikewycz and Heinrichs, 2014) demonstrated that long hay availability with no TMR offered could decrease risk of SARA in lactating dairy cows. This hay availability should also limit the chance of a higher amount of feed being consumed in the first meal after TMR delivery the following day. This condition is often called "slug feeding," and is characterized by a long period of time in which cows remain out of feed, after which they rapidly consume an amount of fermentable carbohydrates able to induce a drop in ruminal pH (Krause and Oetzel, 2005). Cows with TMR available for $19 \mathrm{~h} / \mathrm{d}$ consumed $37.1 \%$ of their hay intake in the $5 \mathrm{~h}$ after TMR was removed, whereas cows with TMR continuously available had $14.4 \%$ of their hay intake in the same period of time. Due to the quality of this hay, cows that had it available had higher intakes of NDF and uNDF. Results of fiber digestibility (totaltract digestibility $>75 \%$ in all the treatments; Table 3 ) appeared to be comparable to values obtained in other experiments, and confirm digestibility shown by Fustini et al. (2017), given the quality of forage used in the dry diets of the Parmigiano Reggiano cheese production area of Italy (Palmonari et al., 2016).

No differences were observed in milk production between the 24- and 19-h feed groups; however, cows that consumed supplemental forage had a tendency for increased milk yield ( 38.03 vs. $35.95 \mathrm{~kg}$, for $\mathrm{F}+$ and $\mathrm{F}-$ respectively, $\mathrm{SEM}=1.63, P=0.09$, Table 4). Cows with TMR access for $19 \mathrm{~h} / \mathrm{d}$ had greater feed efficiency (Table 4) on both a milk volume ( $\mathrm{kg}$ of milk/ $\mathrm{kg}$ of DMI, $P=0.03)$ and component $(\mathrm{kg}$ of ECM $/ \mathrm{kg}$ of DMI, $P=0.05$ ) basis compared with the 24-h group. This improved efficiency is likely a result of longer feed retention times and improved total-tract digestibility. However, BW of cows did not change over the study. No differences were observed in milk protein, fat, and urea content; however, somatic cells tended to be higher for $19 \mathrm{~h} / \mathrm{d}$ TMR diets, in particular when hay was not offered (Table 4). Lactose tended to be higher in milk from cows with 24-h TMR access, likely because of the lower SCC (Table 4).

Rumination times were much higher than values considered as a minimum threshold to ensure rumen functionality (>390 min/d; Zebeli et al., 2007, 2009). An interaction was observed between TMR availability and provision of supplemental hay for rumination time (Table 5). Cows with $19 \mathrm{~h}$ of TMR access ruminated less when hay was offered $(P<0.01)$. In contrast, hay had no effect on rumination time in cows with $24 \mathrm{~h}$ of 
Table 3. Effect of feed restriction and supplemental hay ${ }^{1}$ on fecal fiber content and total-tract fiber digestibility

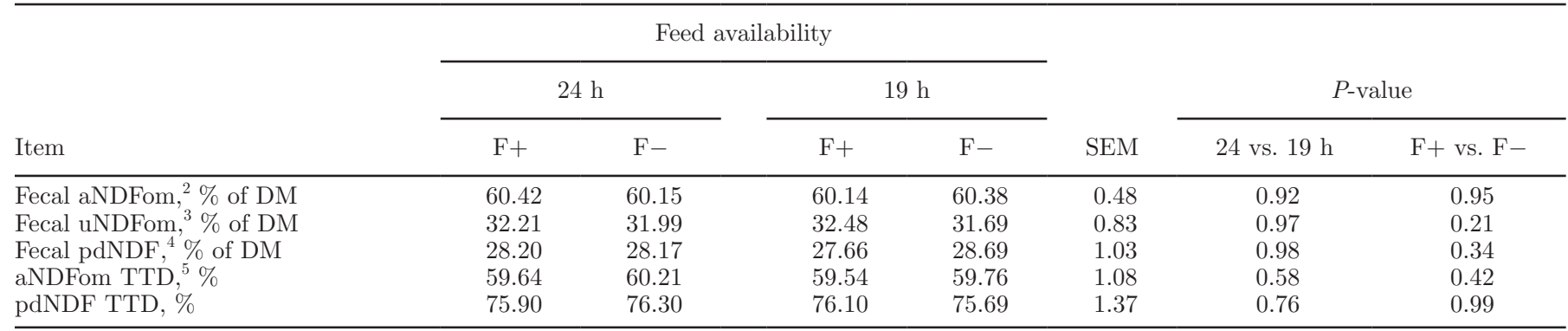

${ }^{1} \mathrm{~F}+=$ supplemental hay; $\mathrm{F}-=$ no supplemental hay.

${ }^{2}$ Amylase- and sodium sulfite-treated NDF with ash correction.

${ }^{3}$ Unavailable NDF estimated via 240 -h in vitro fermentation.

${ }^{4}$ Potentially digestible NDF.

${ }^{5}$ Total-tract fiber digestibility.

TMR access. Rumination time, average reticuloruminal $\mathrm{pH}$ values, and time when $\mathrm{pH}$ was below $\mathrm{pH} 5.8$ and 5.5 are shown in Table 5. The results obtained are reflective of the high-fiber diets used in this study. Time in which the $\mathrm{pH}$ fell below 5.5, the minimum critical threshold, was negligible. Average $\mathrm{pH}$ values were lower $(P<0.05)$ in the diets where long hay was offered, but for no obvious reason. Overall $\mathrm{pH}$ of cows was not affected by diet treatment. This was likely a result of the cows' preference for TMR and their ability to somewhat compensate for total TMR DMI once adapted to the restricted hours of availability (Maulfair et al., 2013), while the group having no access to feed for $5 \mathrm{~h}$ ate less.

No differences were observed regarding average ammonia and ruminal VFA levels, as shown in Table 6 . At $12 \mathrm{~h}$ after feeding $(0800 \mathrm{~h})$ a tendency was observed for lower ammonia for the cows with 19-h TMR access. This could be explained by the lower DMI for the restricted diets that release a higher amount of fermentable carbohydrates, allowing bacteria to consume more nitrogen during the part of the day when feed was available. Conversely, when looking the values obtained $24 \mathrm{~h}$ after feed distribution $(2000 \mathrm{~h})$, acetate, propionate, and total VFA tended to be lower in cows with 19 $\mathrm{h}$ of TMR access, and butyrate was significantly lower. This condition is likely due to the absence of new feed that could have reduced VFA production in the rumen. All other rumen parameters measured were similar. Restricting TMR comprised of dry forages, whereas offering additional long hay appears to be consistent with previous research using silage-based diets (Kmicikewycz and Heinrichs, 2014). In the same research, once cows adapted to the restricted feeding period, the lack of hay made little change to their feed intake and digestion. This approach to feeding may also reduce nutrient excretion due to greater feed digestibility.

Table 4. Effect of feed restriction and supplemental hay ${ }^{1}$ on milk production and quality

\begin{tabular}{|c|c|c|c|c|c|c|c|}
\hline \multirow[b]{3}{*}{ Item } & \multicolumn{4}{|c|}{ Feed availability } & \multirow[b]{3}{*}{ SEM } & \multirow{2}{*}{\multicolumn{2}{|c|}{$P$-value }} \\
\hline & \multicolumn{2}{|c|}{$24 \mathrm{~h}$} & \multicolumn{2}{|c|}{$19 \mathrm{~h}$} & & & \\
\hline & $\mathrm{F}+$ & $\mathrm{F}-$ & $\mathrm{F}+$ & $\mathrm{F}-$ & & 24 vs. $19 \mathrm{~h}$ & $\mathrm{~F}+$ vs. $\mathrm{F}-$ \\
\hline Milk, kg/d & 37.87 & 36.56 & 38.19 & 35.33 & 1.63 & 0.71 & 0.09 \\
\hline $\mathrm{ECM}, \mathrm{kg} / \mathrm{d}$ & 40.26 & 38.23 & 39.13 & 36.84 & 1.33 & 0.13 & 0.01 \\
\hline Milk kg/DMI kg & 1.40 & 1.54 & 1.91 & 1.64 & 0.18 & 0.03 & 0.64 \\
\hline $\mathrm{ECM} \mathrm{kg/DMI} \mathrm{kg}$ & 1.48 & 1.60 & 1.92 & 1.68 & 0.17 & 0.05 & 0.63 \\
\hline Fat, $\%$ & 3.82 & 3.62 & 3.58 & 3.60 & 0.18 & 0.31 & 0.46 \\
\hline Fat yield, $\mathrm{kg} / \mathrm{d}$ & 1.27 & 1.32 & 1.35 & 1.33 & 0.16 & 0.71 & 0.91 \\
\hline Protein, \% & 3.38 & 3.38 & 3.42 & 3.31 & 0.11 & 0.74 & 0.34 \\
\hline Protein yield, $\mathrm{kg} / \mathrm{d}$ & 1.13 & 1.26 & 1.28 & 1.20 & 0.10 & 0.65 & 0.83 \\
\hline Lactose, $\%$ & 4.88 & 4.88 & 4.80 & 4.79 & 0.05 & 0.04 & 0.94 \\
\hline Lactose yield, $\mathrm{kg} / \mathrm{d}$ & 1.65 & 1.83 & 1.86 & 1.75 & 0.15 & 0.68 & 0.85 \\
\hline Urea, \% & 14.68 & 15.42 & 15.30 & 15.53 & 1.36 & 0.72 & 0.65 \\
\hline $\mathrm{SCC}, \log \mathrm{cfu} / \mathrm{mL}$ & 2.39 & 3.49 & 3.38 & 4.00 & 0.80 & 0.07 & 0.04 \\
\hline $\mathrm{BW}$ variation, $\mathrm{kg}$ & 0.52 & -3.48 & 17.63 & 17.47 & 9.60 & 0.08 & 0.85 \\
\hline
\end{tabular}

${ }^{1} \mathrm{~F}+=$ supplemental hay; $\mathrm{F}-=$ no supplemental hay. 
Table 5. Effect of feed restriction and supplemental hay ${ }^{1}$ on rumination time and reticuloruminal $\mathrm{pH}$

\begin{tabular}{|c|c|c|c|c|c|c|c|}
\hline Item & \multicolumn{4}{|c|}{ Feed availability } & SEM & \multicolumn{2}{|c|}{$P$-value } \\
\hline Rumination, $\min / \mathrm{d}$ & $424.98^{\mathrm{a}}$ & $443.10^{\mathrm{a}}$ & $446.26^{\mathrm{a}}$ & $412.22^{\mathrm{b}}$ & 30.49 & 0.62 & 0.41 \\
\hline Daily average $\mathrm{pH}$ & 6.10 & 6.11 & 6.09 & 6.12 & 0.09 & 0.88 & 0.04 \\
\hline Time $\mathrm{pH}<5.8, \min / \mathrm{d}$ & 18.79 & 19.06 & 22.02 & 18.44 & 11.78 & 0.32 & 0.21 \\
\hline
\end{tabular}

$\overline{\mathrm{a}, \mathrm{b}}$ Means with different superscripts differ at $P<0.05$ (significant interaction between effects of feed availability and provision of supplemental hay).

${ }^{1} \mathrm{~F}+=$ supplemental hay; $\mathrm{F}-=$ no supplemental hay.

\section{CONCLUSIONS}

The results obtained in this study show that once cows adapted to diet changes, few differences were observed when offering TMR continuously $24 \mathrm{~h} / \mathrm{d}$ or limited to $19 \mathrm{~h} / \mathrm{d}$. In addition, the presence of long hay during the TMR restriction offered the best conditions for ruminal function and $\mathrm{pH}$ stability and tended to improve milk production. It was noted that a restriction of TMR availability for $5 \mathrm{~h} / \mathrm{d}$ can potentially increase feed efficiency, as has been shown in other classes of ru- minants. These results need to be confirmed by longer duration experiments using mid-lactation dairy cows. A Latin square with 21-d periods could have a carry-over effect on energy storage and mobilization of fat reserves might be able to mask negative energy balance during restriction. However, in our experiment we did not see any BW variation. This feeding system could be used as a strategy to manage feed availability according to cow production and metabolic condition and to maximize the use of nutrient resources, reducing the cost of milk production and improving the cows' welfare and health.

Table 6. Effect of feed restriction and supplemental hay ${ }^{1}$ on ruminal VFA and ammonia content

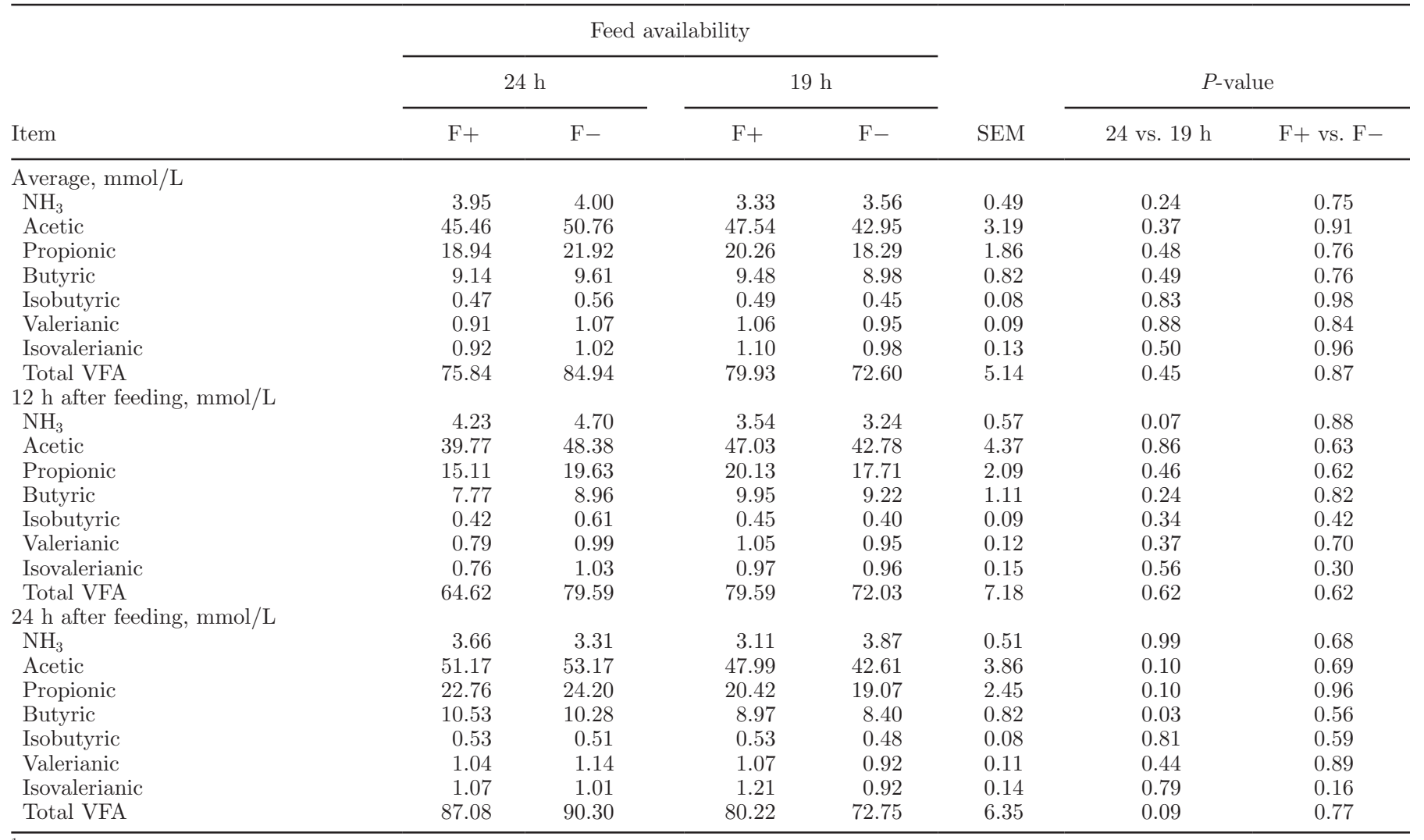

${ }^{1} \mathrm{~F}+=$ supplemental hay; $\mathrm{F}-=$ no supplemental hay. 


\section{ACKNOWLEDGMENTS}

This research was supported by The University of Bologna, Bologna, Italy, and was carried out when the corresponding author (A. J. Heinrichs) was on a sabbatical from The Pennsylvania State University.

\section{REFERENCES}

Albright, J. L. 1993. Feeding behavior of dairy cattle. J. Dairy Sci. $76: 485-498$.

AOAC International. 2016. Official Methods of Analysis. 20th ed. AOAC International, Arlington, VA.

Beauchemin, K. A., B. I. Farr, L. M. Rode, and G. B. Shaalje. 1994 Effects of alfalfa silage chop length and supplementary long hay on chewing and milk production of dairy cows. J. Dairy Sci. 77:13261339.

Bhatti, S. A., J. G. Bowman, J. L. Firkins, A. V. Grove, and C. W. Hunt. 2008. Effect of intake level and alfalfa substitution for grass hay on ruminal kinetics of fiber digestion and particle size passage in beef cattle. J. Anim. Sci. 86:134-145.

DeVries, T. J., F. Dohme, and K. A. Beauchemin. 2008. Repeated ruminal acidosis challenges in lactating dairy cows at high and low risk for developing acidosis: Feed sorting. J. Dairy Sci. 91:3958 3967.

Fustini, M., A. J. Heinrichs, A. Palmonari, and A. Formigoni. 2016. Farm characteristics and total mixed ration particle size issues on Parmigiano Reggiano farms in Northern Italy. Prof. Anim. Sci. 32:869-873.

Fustini, M., A. Palmonari, G. Canestrari, E. Bonfante, L. Mammi, M. T. Pacchioli, G. C. J. Sniffen, R. J. Grant, K. W. Cotanch, and A. Formigoni. 2017. Effect of undigested neutral detergent fiber content of alfalfa hay on lactating dairy cows: Feeding behavior, fiber digestibility, and lactation performance. J. Dairy Sci. 100:4475-4483.

Gasteiner, J., M. Fallast, S. Rosenkranz, J. Häusler, K. Schneider, and T. Guggenberger. 2009. Measuring rumen $\mathrm{pH}$ and temperature by an indwelling and data transmitting unit and application under different feeding conditions. Wien. Tierarztl. Monatsschr. 96:188-194.

Goering, H. K., and P. J. Van Soest. 1970. Forage Fiber Analysis (Apparatus, Reagents, Procedures, and Some Applications). Agriculture Handbook No. 379. ARS-USDA, Washington, DC.

Goetsch, A. L., and M. L. Galyean. 1983. Influence of feeding frequency on passage of fluid and particulate markers in steers fed a concentrate diet. Can. J. Anim. Sci. 63:727-730.

Heinrichs, A. J. 2013. The Penn State Particle Separator. DSE 2013 186. Accessed Jan 5, 2018. https://extension.psu.edu/penn-state -particle-separator.

Keunen, J. E., J. C. Plaizier, L. Kyriazakis, T. F. Duffield, T. M Widowski, M. I. Lindinger, and B. W. McBride. 2002. Effects of a subacute ruminal acidosis model on the diet selection of dairy cows. J. Dairy Sci. 85:3304-3313.

Khafipour, E., S. Li, C. Plaizier, and D. O. Krause. 2009. Rumen microbiome composition determined using two nutritional models of subacute ruminal acidosis. Appl. Environ. Microbiol. 75:71157124

Klevenhusen, F., P. Pourazad, S. U. Wetzels, M. Qumar, and A. KholParisini. 2014. Technical note: Evaluation of a real-time wireless $\mathrm{pH}$ measurement system relative to intraruminal differences of digesta in dairy cattle. J. Anim. Sci. 92:5635-5639.

Kmicikewycz, A. D., K. J. Harvatine, and A. J. Heinrichs. 2015. Effects of corn silage particle size, supplemental hay, and forage- to-concentrate ratio on rumen $\mathrm{pH}$, feed preference, and milk fat profile of dairy cattle. J. Dairy Sci. 98:4850-4868.

Kmicikewycz, A. D., and A. J. Heinrichs. 2014. Feeding lactating dairy cattle long hay separate from the total mixed ration can maintain dry matter intake during incidents of low rumen $\mathrm{pH}$. J. Dairy Sci. 97:7175-7184.

Krause, K. M., and G. R. Oetzel. 2005. Inducing subacute ruminal acidosis in lactating dairy cows. J. Dairy Sci. 88:3633-3639.

Lammers, B. P., D. R. Buckmaster, and A. J. Heinrichs. 1996. A simple method for the analysis of particle sizes of forage and total mixed rations. J. Dairy Sci. 79:922-928.

Maulfair, D. D., M. Fustini, and A. J. Heinrichs. 2011. Effect of varying total mixed ration particle size on rumen digesta and fecal particle size and digestibility in lactating dairy cows. J. Dairy Sci. 94:3527-3536.

Maulfair, D. D., K. K. McIntyre, and A. J. Heinrichs. 2013. Subacute ruminal acidosis and total mixed ration preference in lactating dairy cows. J. Dairy Sci. 96:6610-6620.

Mertens, D. R. 1977. Dietary fiber components: Relationship to the rate and extent of ruminal digestion. Fed. Proc. 36:187-192.

Mertens, D. R. 1997. Creating a system for meeting the fiber requirements of dairy cows. J. Dairy Sci. 80:1463-1481.

Mertens, D. R., M. Allen, J. Carmany, J. Clegg, A. Davidowicz, M. Drouches, K. Frank, D. Gambin, M. Garkie, B. Gildemeister, D. Jeffress, C. S. Jeon, D. Jones, D. Kaplan, G. N. Kim, S. Kobata, D. Main, X. Moua, B. Paul, J. Robertson, D. Taysom, N. Thiex, J. Williams, and M. Wolf. 2002. Gravimetric determination of amylase-treated neutral detergent fiber in feeds with refluxing in beakers or crucibles. J. AOAC Int. 85:1217-1240.

NRC. 2001. Nutrient Requirements of Dairy Cattle. 7th rev. ed. Natl. Acad. Press, Washington, DC.

Owens, F. N.. D. R. Gill, D. S. Secrest, and S. W. Coleman. 1995. Review of some aspects of growth and development of feedlot cattle. J. Anim. Sci. 73:3152-3172.

Palmonari, A., G. Canestrari, E. Bonfante, M. Fustini, L. Mammi, and A. Formigoni. 2017. Technical note: In vitro digestibility of amylase-treated, ash-corrected neutral detergent fiber, with addition of sodium sulfite, at 240 hours with or without rumen fluid reinoculation. J. Dairy Sci. 100:1200-1202.

Palmonari, A., A. Gallo, M. Fustini, G. Canestrari, F. Masoero, C. J. Sniffen, and A. Formigoni. 2016. Estimation of the indigestible fiber in different forage types. J. Anim. Sci. 94:248-254.

Schirmann, K., M. A. G. von Keyserlingk, D. M. Weary, D. M. Veira, and W. Heuwieser. 2009. Validation of a system for monitoring rumination in dairy cows. J. Dairy Sci. 92:6052-6055.

Tilley, J. M. A., and R. A. Terry. 1963. A two-stage technique for the in vitro digestion of forage crops. Grass Forage Sci. 18:104-111.

Van Soest, P. J. 1994. Nutritional Ecology of the Ruminant. Cornell University Press, Ithaca, NY.

Van Soest, P. J., J. B. Robertson, and B. A. Lewis. 1991. Methods for dietary fiber, neutral detergent fiber, and nonstarch polysaccharides in relation to animal nutrition. J. Dairy Sci. 74:3583-3597.

Zanton, G. I., and A. J. Heinrichs. 2008. Rumen digestion and nutritional efficiency of dairy heifers limit-fed a high forage ration to four levels of dry matter intake. J. Dairy Sci. 91:3579-3588.

Zebeli, Q., M. Tafaj, I. Weber, J. Dijkstra, H. Steingass, and W. Drochner. 2007. Effects of varying dietary forage particle size in two concentrate levels on chewing activity, ruminal mat characteristics, and passage in dairy cows. J. Dairy Sci. 90:1929-1942.

Zebeli, Q. J., D. Mansman, H. Steingass, and B. N. Ametaj. 2009. Balancing diets for physically effective fibre and ruminally degradable starch: A key to lower the risk of sub-acute rumen acidosis and improve productivity of dairy cattle. Livest. Sci. 127:1-10. 